\title{
Urea in sugarcane-based diets for dairy cows ${ }^{1}$
}

\author{
Alberto Magno Ferreira Santiago ${ }^{2}$, José Maurício de Souza Campos ${ }^{3}$, André Soares de \\ Oliveira $^{4}$, Sebastião de Campos Valadares Filho ${ }^{5}$, Stefanie Alvarenga Santos ${ }^{5}$, Shirley Motta de \\ Souza $^{5}$, lara Furtado Santiago ${ }^{6}$
}

\author{
${ }^{1}$ Financed by CNPq \\ ${ }^{2}$ Instituto Federal de Educação, Ciência e Tecnologia, Campus Rio Pomba-MG, Brazil. \\ ${ }^{3}$ Universidade Federal Rural de Pernambuco, Unidade Acadêmica de Garanhuns. Researcher at CNPq. \\ ${ }^{4}$ Instituto de Ciências Agrárias e Ambientais, Universidade Federal de Mato Grosso, Campus Sinop. Researcher at INCT/Ciência Animal/CNPq. \\ ${ }^{5}$ Departamento de Zootecnia, Universidade Federal de Viçosa, Campus Viçosa. \\ ${ }^{6}$ Universidade Federal de Ouro Preto.
}

\begin{abstract}
We evaluated the effect of adding four levels $(0,4,8$ and $12 \mathrm{~g} / \mathrm{kg}$, as fed) of a mixture (9:1) of urea and ammonium sulfate (UAs) to sugarcane on feed intake and digestibility, productive performance and metabolism of nitrogen compounds of dairy cows. Twelve multiparous Holstein cows $(12.6 \pm 0.5 \mathrm{~kg} / \mathrm{d}$ of milk, $225 \pm 90$ days in milk) were distributed in three $4 \times 4$ Latin squares, receiving diets with the same amount of nitrogen ( $125 \mathrm{~g}$ crude protein $/ \mathrm{kg}$ of dry matter). Concentrate feed was supplied at a ratio of $1 \mathrm{~kg}$ for each $3 \mathrm{~kg}$ of milk produced. The sugarcane presented $21.9^{\circ} \mathrm{Brix}$. The level of UAs did not affect intake, total digestibility of diet components, milk production or milk components. Increasing UAs level linearly increased concentration of plasma urea nitrogen (PUN), urinary excretion of nitrogen and contribution of non-urea nitrogen in the urinary excretion and linearly reduced milk production/urinary excretion of nitrogen ratio. In spite of the linear increase of PUN with increased urea, the maximum value observed $(14.31 \mathrm{mg} / \mathrm{dL})$ was below the threshold value of $20 \mathrm{mg} / \mathrm{dL}$, above which reproductive function may be compromised. In diets with sugarcane for dairy cows with production below $15 \mathrm{~kg} / \mathrm{day}$, the UAs level may be raised from 0 to $12 \mathrm{~g} / \mathrm{kg}$ natural matter without impairing performance.
\end{abstract}

Key Words: metabolism, milk production, nitrogen

\section{Introduction}

Sugarcane is characterized as a forage of high yield, with high levels of carbohydrates rapidly fermented in the rumen, but poor in protein, in addition to presenting fibrous components of low extent of rumen degradation, implying limitations in the ingestion of dry matter (Fernandes, 2001).

The increase of concentrate in diet is an alternative to circumvent the limitations of dry matter intake imposed by sugarcane, but raises the cost with feeding (Costa et al., 2005). Thus, the utilization of low-cost ingredients per unit of nutrient becomes necessary.

The inclusion of urea as a source of nitrogen compounds is an alternative to reduce the costs with feeding, due to its lower cost per unit of nitrogen in relation to the sources of true vegetable protein. However, the addition of up to $20 \mathrm{~g}$ urea $/ \mathrm{kg} \mathrm{DM}$ in the diet to diets based on corn or sorghum silage has been show to decrease intake and performance of dairy cows (Melo et al., 2003; Oliveira et al., 2004).

Inpioneering research studies, the sensory characteristics of urea (odor and taste) were pointed as the main factor responsible for the deleterious effect on intake in ruminants
(Huber \& Cook, 1972; Chalupa et al., 1979). However, in a study comparing the supply of diets containing 1 or $3 \%$ urea for Holstein cows and steers, provided orally or via rumen, greater reduction was observed in intake when more elevated levels of urea were supplied through the rumen (Wilson et al., 1975). These effects demonstrated that physiological reactions are involved in the alteration of intake and not sensory characteristics.

In these assumptions, it was speculated that due to the high content of sugars in diets based on sugarcane, it was possible to raise the level of urea without compromising animal intake and productive performance, since a greater amount of ammonia could be assimilated by the rumen microbiota. However, elevations in the hepatic ureagenesis could increase the losses of urine nitrogen, compromising the utilization efficiency of the dietary nitrogen compounds (Van Amburgh \& Peterson, 2004).

Our objective was to verify the effect of different levels of urea in sugarcane $(0,4,8$ and $12 \mathrm{~g} / \mathrm{kg}$, as fed) on diet intake and digestibility, productive performance, metabolism of nitrogen compounds and economic viability of diets in dairy cows with production below $15 \mathrm{~kg} /$ day. 


\section{Material and Methods}

The experiment took place at the Unit of Research, Teaching and Extension on Beef Cattle of the Department of Animal Science, at Universidade Federal de Viçosa, in the period from July to September 2006. Twelve purebred and crossbred Holstein cows, with lactation length of $225 \pm 90$ days (during experiment) were distributed in three $4 \times 4$ Latin squares, according to the lactation period. The experiment was comprised of four 18-day periods, of which the first day was used for acclimatization, and the others for evaluation of intake, digestibility, milk production and composition, excretion of nitrogen compounds and nitrogen balance.

Animals were subjected to four treatments, corresponding to four different levels of a mixture of nine parts of urea and one part of ammonium sulfate (UAs) in the sugarcane (Saccharum officinarum, L., variety RB 73-9735): 0, 4, 8 and $12 \mathrm{~g} / \mathrm{kg}$ in the natural matter. Diets were formulated to contain the same amount of nitrogen, with $125 \mathrm{~g}$ crude protein $/ \mathrm{kg}$ dry matter. One kilogram (as-is basis) of concentrate feed was offered for each $3 \mathrm{~kg}$ of milk produced, which was equivalent to the supply of diets with an average roughage:concentrate ratio of 70:30, at the beginning of the experiment. Concentrate supply was adjusted on the fifth and tenth days of each adaptation period (Tables 1 and 2).

Table 1 - Proportion of ingredients $(\mathrm{g} / \mathrm{kg} \mathrm{DM})$ in concentrate according to UAs levels in sugarcane

\begin{tabular}{lcccc}
\hline \multirow{2}{*}{ Ingredients } & \multicolumn{4}{c}{ UAs levels in sugarcane $(\mathrm{g} / \mathrm{kg}$ as fed) } \\
\cline { 2 - 5 } & 0 & 4 & 8 & 12 \\
\hline Ground corn & 136.7 & 309.2 & 494.0 & 692.6 \\
Wheat meal & 200.0 & 206.9 & 214.3 & 222.2 \\
Soybean meal & 606.7 & 418.4 & 216.7 & 00.0 \\
Minerals & 56.7 & 65.5 & 75.0 & 85.2 \\
\hline
\end{tabular}

DM - dry matter; UAs - mixture consisting of 9 parts of urea: 1 part of ammonium sulphate, as fed.
Animals were handled in individual tie-type stalls, where they received feed ad libitum twice daily, at $7 \mathrm{~h} 00$ and $16 \mathrm{~h} 00$, allowing for leftovers at $10 \mathrm{~g} / \mathrm{kg}$ of natural matter (NM) offered. In the collection period, the quantities of sugarcane, urea and concentrate (Table 3 ) feeds supplied and leftovers from each treatment were weighed and sampled twice daily. Samples were stored at $-15{ }^{\circ} \mathrm{C}$ for subsequent chemical analyses. The Brix degree of the juice obtained from ten sugarcane stalks was measured daily, using a Zeiss ${ }^{\circledR}$ refractometer.

Feces were collected directly from the rectal ampulla once daily, at $10 \mathrm{~h} 00,12 \mathrm{~h} 00,14 \mathrm{~h} 00,16 \mathrm{~h} 00$ and $18 \mathrm{~h} 00$ from the 12th to the 16th day of each experimental period. Daily samples of feces from each animal, in each period, were stored at $-15{ }^{\circ} \mathrm{C}$ for subsequent drying and chemical analyses.

Samples of sugarcane, leftovers and feces were dried in a forced-ventilation oven $\left(60^{\circ} \mathrm{C}\right.$ for 72 hours $)$ and, along with those of the feedstuffs, they were processed in knife mill with $1 \mathrm{~mm}$ sieve for chemical analysis and in situ rumen incubation (Casali, 2006). Composite samples from the daily samples of air-dried feces of each animal were made for further chemical analysis.

The analyses of DM, total N, acid detergent fiber (ADF) and lignin (sulfuric acid) contents were performed according to methods described in Silva \& Queiroz (2002). For the analysis of the neutral detergent fiber (NDF), samples were treated with thermostable alpha-amylase without the use of sodium sulfite, corrected for the ash residue (Mertens, 2002) and for the residue of nitrogen compounds (Licitra et al., 1996). Analyses of NDF and ADF were performed in an Ankom $^{\circledR}$ system using TNT (non-woven textile) bags with dimensions $5 \times 5 \mathrm{~cm}$, keeping average ratios of $14 \mathrm{mg}$ $\mathrm{DM} / \mathrm{cm}^{2}$ fabric and neutral detergent at $100 \mathrm{~mL} / \mathrm{g}$ of airdried sample. The non-protein nitrogen (NPN) of the feed was determined according to Licitra et al. (1996).

Table 2 - Chemical composition of ingredients

\begin{tabular}{|c|c|c|c|c|}
\hline Item & Sugarcane & Ground corn & Wheat bran & Soybean meal \\
\hline Dry matter $(\mathrm{g} / \mathrm{kg})$ & 283.0 & 887.3 & 890.3 & 895.1 \\
\hline $\operatorname{Ash}^{1}$ & 40.3 & 9.5 & 50.1 & 65.4 \\
\hline Ether extract ${ }^{1}$ & 7.6 & 29.5 & 25.5 & 13.1 \\
\hline Crude protein $^{1}$ & 25.6 & 89.9 & 176.3 & 511.0 \\
\hline Non-protein nitrogen ${ }^{2}$ & 110.1 & 165.8 & 171.8 & 97.2 \\
\hline Neutral detergent insoluble nitrogen ${ }^{2}$ & 253.9 & 96.8 & 208.1 & 38.4 \\
\hline Acid detergent insoluble nitrogen ${ }^{2}$ & 80.8 & 32.3 & 25.4 & 10.2 \\
\hline Neutral detergent fiber corrected for residual ash and protein ${ }^{1}$ & 421.5 & 127.3 & 410.6 & 125.4 \\
\hline Non-fibrous carbohydrates corrected for residual ash and protein ${ }^{1}$ & 505.0 & 743.8 & 337.5 & 285.1 \\
\hline Total carbohydrates ${ }^{1}$ & 926.5 & 871.1 & 748.1 & 410.5 \\
\hline Acid detergent fiber ${ }^{1}$ & 258.0 & 28.2 & 139.6 & 63.2 \\
\hline Acid detergent lignin ${ }^{1}$ & 43.4 & 6.4 & 32.6 & 5.1 \\
\hline Indigestible neutral detergent fiber ${ }^{1}$ & 212.7 & 13.1 & 110.3 & 5.6 \\
\hline
\end{tabular}


Table 3 - Composition of concentrate according to different UAs levels in sugarcane

\begin{tabular}{|c|c|c|c|c|}
\hline \multirow{2}{*}{ Item } & \multicolumn{4}{|c|}{ UAs in sugarcane $(\mathrm{g} / \mathrm{kg}$ as fed $)$} \\
\hline & 0 & 4 & 8 & 12 \\
\hline Dry matter $(\mathrm{g} / \mathrm{kg})$ & 898.3 & 897.8 & 897.2 & 866.6 \\
\hline $\mathrm{Ash}^{1}$ & 107.7 & 106.2 & 104.6 & 102.9 \\
\hline Crude protein ${ }^{1}$ & 357.6 & 278.1 & 192.9 & 101.4 \\
\hline Non-protein nitrogen ${ }^{2}$ & 107.6 & 114.4 & 128.1 & 168.2 \\
\hline Neutral detergent insoluble nitrogen ${ }^{2}$ & 57.1 & 66.5 & 85 & 139.8 \\
\hline Non-fibrous carbohydrates corrected for residual ash and protein ${ }^{1}$ & 342 & 419.1 & 501.5 & 590.1 \\
\hline Total carbohydrates ${ }^{1}$ & 517.6 & 595.9 & 679.6 & 769.5 \\
\hline Acid detergent fiber ${ }^{1}$ & 70.1 & 64 & 57.5 & 50.6 \\
\hline Acid detergent lignin ${ }^{1}$ & 10.5 & 10.9 & 12.3 & 13 \\
\hline Indigestible neutral detergent fiber ${ }^{1}$ & 27.2 & 29.2 & 31.3 & 33.6 \\
\hline
\end{tabular}

UAs - mixture consisting of 9 parts of urea: 1 part of ammonium sulphate, as fed.

${ }^{1} \mathrm{~g} / \mathrm{kg}$ DM.

$2 \mathrm{~g} / \mathrm{kg}$ total nitrogen.

Non-fibrous carbohydrates corrected for residual ash and protein $\left(\mathrm{NDF}_{\text {ap }}\right)$ were calculated as suggested by Hall (2000), with modifications, as follows: $\mathrm{NFC}_{\text {ap }}(\mathrm{kg} / \mathrm{kg} \mathrm{DM})$ $=1-\left(\mathrm{CP}-\mathrm{CP}\right.$ from urea + urea in the diet $+\mathrm{NDF}_{\text {ap }}+\mathrm{EE}+$ Ash). Total digestible nutrients (TDN) were calculated with adaptations to the description of Weiss (1999), through the following equation: $\mathrm{TDN}(\%)=\mathrm{DCP}+\mathrm{DNDF}_{\mathrm{ap}}+\mathrm{DNFC}_{\mathrm{ap}}$ $+2.25 \mathrm{DEE}$, in which: $\mathrm{DCP}=$ digestible crude protein; $\mathrm{DNDF}_{\mathrm{ap}}=$ digestible neutral detergent fiber; $\mathrm{DNFC}_{\mathrm{ap}}=$ digestible non-fibrous carbohydrates; and DEE = digestible ether extract.

The total amount of fecal DM excreted was estimated by the concentration of indigestible neutral detergent fiber (iNDF) obtained after rumen incubation of feeds, leftovers and feces in polyester bags $\left(\right.$ Ankon $^{\circledR}$, filter bag 57) for a period of 264 hours, according to Casali (2006).

Cows were milked mechanically twice daily, recording the production of milk from the 12th to the 18th day of each experimental period. Through devices attached to the milking machines, samples of milk of approximately $300 \mathrm{~mL}$ were collected on the 14th and 15th days in the morning and afternoon milking sessions, with the use of composite samples from each day, according to the milk yield. From the composite samples of each day, aliquots $(50 \mathrm{~mL})$ were extracted and conditioned in plastic containers with preservatives (Bronopol ${ }^{\circledR}$ ) kept between 2 and $6{ }^{\circ} \mathrm{C}$ and sent to the Laboratory of Analysis of Milk Quality of Embrapa Gado de Leite, for determination of the contents of lactose, fat, total solids and nonfat solids of the milk, according to the methodology described by the International Dairy Federation (1996). Milk yield (MY) corrected for $35 \mathrm{~g}$ fat $/ \mathrm{kg}$ (CMY) was calculated according to Sklan et al. (1992).

On the seventh day of adaptation and at the end of each experimental period, animals were weighed individually for evaluation of variation in weight. The weights corresponded to the averages of two weighing sessions, performed before the supply of feed and after milking.

Blood samples were collected on the 17th day, with test tubes with anticoagulant (EDTA), centrifuged at 2,300 $\mathrm{xg}$ for 15 minutes, and then plasma samples were collected for subsequent analysis of urea.

Spot samples of urine were obtained from all cows on the 13th day of each experimental period, during urination stimulated by vulva massage four hours after feeding. Urine samples were filtered and stored at $-15^{\circ} \mathrm{C}$ for subsequent analyses of total nitrogen, urea and creatinine. Immediately before analyses, samples were thawed and centrifuged at 2,000 $\mathrm{xg}$ for 15 minutes.

Urea was analyzed by enzymatic colorimetry (urease method), with the aid of commercial kits (Labtest Diagnóstica S.A.). Analyses of creatinine in the urine were performed via endpoint with picrate and acidifying, with commercial kits (Labtest Diagnóstica S.A.).

The total urinary volume was estimated by dividing the daily urinary excretions of creatinine by the values of creatinine observed in the urine, in accordance with Valadares Filho \& Valadares (2001). The urinary excretion of creatinine was estimated from the $24.05 \mathrm{mg}$ creatinine $/ \mathrm{kg}$ live weight (LW) proposed by Chizzotti et al. (2008).

The balance of nitrogen compounds (NB) was obtained by the difference between the total nitrogen ingested (Ning) and the total nitrogen excreted in the feces (N-feces), excreted in the urine (N-urine) and secreted in the milk (N-milk). Total nitrogen in the feces and urine were determined according to technique described in Silva \& Queiroz (2002).

The data were subjected to analysis of variance, by decomposing the effect of treatment in three orthogonal 
contrasts: linear, quadratic and cubic effect of urea. The level adopted for probability of type I error was 0.05 . Because of absence of cubic effect of the urea level, it was suppressed from the results. The analyses were performed through procedure PROC GLM of software SAS (Statistical Analysis System, version 9.1).

The variables were analyzed according to the statistical model:

$$
\mathrm{Y}_{\mathrm{ijkl}}=\mu+\mathrm{S}_{\mathrm{i}}+\mathrm{T}_{\mathrm{j}}+(\mathrm{P} / \mathrm{S})_{\mathrm{ik}}+(\mathrm{C} / \mathrm{S})_{\mathrm{il}}+\mathrm{SxT}_{\mathrm{ij}}+\mathrm{e}_{\mathrm{ijkl}},
$$
where:

$\mathrm{Y}_{\mathrm{ijkl}}=$ observation in cow 1 , in period $\mathrm{k}$, subjected to treatment $j$, in Latin square $i ; \mu=$ overall constant; $S_{i}=$ effect of Latin square $\mathrm{i}$, where $\mathrm{i}=1,2,3 ; \mathrm{T}_{\mathrm{j}}=$ effect of treatment $\mathrm{j}$, where $\mathrm{j}=1,2,3,4$; $(\mathrm{P} / \mathrm{S})_{\mathrm{ik}}=$ effect of period $\mathrm{k}$, within Latin square $\mathrm{i}$, where $\mathrm{k}=1,2,3,4 ;(\mathrm{C} / \mathrm{S})_{\mathrm{il}}=$ effect of cow 1 , within Latin square $\mathrm{i}$, where $1=1,2,3,4 ; \mathrm{SxT}_{\mathrm{ij}}=$ effect of interaction between the Latin suquare $i$ and treatment $j$; and $\mathrm{e}_{\mathrm{ijkl}}=$ random error, associated with each observation, NID assumption $\left(0 ; \sigma^{2}\right)$.

\section{Results and Discussion}

As expected, the main chemical alteration in the diet with increase in the level of UAs in the sugarcane occurred at the composition of nitrogen compounds, with enlargement of the fraction of non-protein nitrogen (NPN) at the expense of the protein fraction, with estimated values of $108,316,517$ and $694 \mathrm{~g}$ of NPN/kg of total nitrogen for diets with $0,4,8$ and $12 \mathrm{~g}$ UAs/kg sugarcane.

The sugarcane stalk presented mean value of $21.9^{\circ}$ Brix. Considering the proportion of feeds supplied, the proportion of sugarcane along with UAs was 747.1; 741.9; 751.8; and $746.9 \mathrm{~g} / \mathrm{kg} \mathrm{DM}$ of the diet for levels $0,4,8$ and $12 \mathrm{~g} \mathrm{UAs} / \mathrm{kg}$ of sugarcane. Based on this ratio, the dietary contents of crude protein of $110,118,120$ and $123 \mathrm{~g} / \mathrm{kg}$ DM were estimated.
The addition of up to $12 \mathrm{~g} / \mathrm{kg}$ did not affect $(\mathrm{P}>0.05)$ dry matter intake (DMI) and, consequently, the consumption of the other diet components (Table 4). This result is consistent with Rangel et al. (2008), who did not observe effect of the source of nitrogen (soybean meal vs. urea) and of the level of UAs in the sugarcane $(4,8$ and $12 \mathrm{~g} / \mathrm{kg}$ of sugarcane, as fed) on the intake of dairy cows with milk production above $20 \mathrm{~kg} /$ day. However, it contradicts other researchers who observed linear decrease in the DMI of dairy cows with increase in urea up to the level between 21 and $24 \mathrm{~g} / \mathrm{kg}$ DM of the diet, but utilizing corn or sorghum silages or a mixture of corn silage and forage cactus (Silva et al., 2001a,b; Melo et al., 2003; Oliveira et al., 2004).

In spite of the elevated level of urea in the diet (up to $30 \mathrm{~g} / \mathrm{kg} \mathrm{DM}$ ), the absence of effect on intake is probably related to the pool of ammonia in the blood circulation, which probably remained at thresholds lower than the necessary to cause malfunctioning of the body tissues by energy deficit, especially the brain tissue, with consequent reduction of intake (Detmann et al., 2007). The increase in ammonia concentration in the brain tissue requires increased use of carbon skeletons used in the Krebs cycle to export excess of ammonia, such as glutamate, causing discomfort by energy deficit, and consequent decreased intake.

The concentration of plasma urea nitrogen (PUN) increased linearly $(\mathrm{P}<0.05)$ with increasing doses of UAs (Table 4). The concentration of PUN is directly proportional to the concentration of circulating ammonia (Van Amburgh \& Peterson, 2004). The PUN level in the cows receiving sugarcane with $12 \mathrm{~g} \mathrm{UAs} / \mathrm{kg}(14.31 \mathrm{mg} / \mathrm{dL})$ was similar to that observed by Rangel et al. (2008), in cows receiving sugarcane with the same UAs level, without effect on intake. The PUN value in this study was, however, smaller than values observed in studies in which intake reduced as UAs were increased (from 19.90 to $23.08 \mathrm{mg} / \mathrm{dL}$ ) (Silva et al. 2001a,b; Oliveira et al., 2001; Oliveira et al., 2004).

Table 4 - Nutrient intake in dairy cows fed different UAs levels in sugarcane

\begin{tabular}{|c|c|c|c|c|c|c|c|}
\hline \multirow{2}{*}{ Item } & \multicolumn{4}{|c|}{ UAs in sugarcane ( $\mathrm{g} / \mathrm{kg}$ as fed) } & \multicolumn{2}{|c|}{ Effect (P-value) } & \multirow{2}{*}{ CV $(\%)$} \\
\hline & 0 & 4 & 8 & 12 & Linear & Quadratic & \\
\hline Dry matter, kg & 14.15 & 14.17 & 14.22 & 13.93 & 0.5729 & 0.5333 & 5.81 \\
\hline Organic matter, kg & 13.33 & 13.38 & 13.47 & 13.20 & 0.7468 & 0.4976 & 5.85 \\
\hline Ether extract, $\mathrm{kg}$ & 0.1475 & 0.1555 & 0.1492 & 0.1575 & 0.2387 & 0.9753 & 9.78 \\
\hline Crude protein, $\mathrm{kg}$ & 1.63 & 1.64 & 1.64 & 1.65 & 0.7000 & 0.9260 & 6.65 \\
\hline NDFap, kg & 4.84 & 4.85 & 4.76 & 4.72 & 0.4269 & 0.8319 & 8.86 \\
\hline NFCap, kg & 6.72 & 6.74 & 6.91 & 6.67 & 0.9529 & 0.3404 & 6.73 \\
\hline Total digestible nutrients, $\mathrm{kg}$ & 9.90 & 9.91 & 9.95 & 9.92 & 0.8982 & 0.9161 & 5.41 \\
\hline Dry matter, kg BW & 24.2 & 24.4 & 24.0 & 24.0 & 0.6465 & 0.7814 & 5.50 \\
\hline NDFap, kg BW & 8.3 & 8.4 & 8.0 & 8.1 & 0.4254 & 0.9945 & 8.24 \\
\hline Plasma urea nitrogen $(\mathrm{mg} / \mathrm{dL})$ & 7.76 & 11.99 & 13.15 & 14.31 & $<0.00011$ & 0.0515 & 20.09 \\
\hline
\end{tabular}

UAs - mixture consisting of 9 parts of urea: 1 part of ammonium sulphate; CV - coefficient of variation.

NDFap - neutral detergent fiber corrected for residual ash and protein; NFCap - non-fibrous carbohydrates corrected for residual ash and protein; BW - body weight.

${ }^{1} \hat{\mathrm{Y}}=8.8763+0.49640 . \mathrm{UAs}(\mathrm{g} / \mathrm{kg}) \mathrm{R}^{2}=0.4094$. 
The lower PUN value observed in the present study in relation to those of Silva et al. (2001a,b), Melo et al. (2003) and Oliveira et al. (2004) is possibly related to the nature of the dietary carbohydrates present in the sugarcane, which are mostly soluble in neutral detergent, especially those rich in sugars, of higher rumen degradation rate in relation to the amylaceous fractions, and the ones insoluble in neutral detergent, which are typical in silages of corn and sorghum (Lanzas et al., 2007). A higher rumen degradation rate of the fraction of sugars propitiates greater synchrony with the rate of rumen ammonia availability through urea, allowing for lower accumulation of rumen ammonia (Nocek \& Russell, 1988).

No effects of the level of urea (0 to $12 \mathrm{~g} / \mathrm{kg}$ ) in the sugarcane were observed on the digestibility coefficient of the dry matter or the other diet components (Table 5). The effective digestibility of the diet is a consequence of the potential digestibility, which is a characteristic intrinsic of feedstuffs, of the activity of the microbial and animal enzymatic systems (Detmann et al., 2008). The activity of the microbial and enzymatic systems, in turn, depends on the supply of carbon skeletons, energy, nitrogen compounds and other essential nutrients. In this sense, these results demonstrate that the increase in the NPN fraction from 108 to $694 \mathrm{~g} / \mathrm{kg}$ total nitrogen in diets based on sugarcane does not affect the activity of the microbial enzymatic systems.

Milk yield (MY), 3.5\% fat-corrected milk yield (FCM), DMI efficiency, as well milk components were not affected by UAs level (Table 6). This result is consistent with Rangel et al. (2008), who, utilizing the same levels of urea in the sugarcane, but with a lower roughage:concentrate ratio in relation to the present study, also did not observe effect on the performance of dairy cows with production above 20 $\mathrm{kg} /$ day. However, it is not in line with other researchers, who observed linear decrease in the milk yield of cows fed increasing levels of urea (up to 21 to $24 \mathrm{~g} / \mathrm{kg}$ DM of the diet), but utilizing corn or sorghum silage or a mixture of corn silage and forage cactus as exclusive source of forage (Silva et al., 2001a; Melo et al., 2003; Oliveira et al., 2004).

Absence of effect on intake and digestibility of the diet components is the main factor to explain the absence of effect on cow productive performance. Although the production of rumen microbial protein was not measured, the behavior of animal performance also indicates absence of effect of UAs level on the supply of metabolizable protein, especially of the rumen microbial fraction. The variation in body weight was not affected by UAs level, with an average $0.5 \mathrm{~kg} /$ cow.day.

Although no significant effects were detected $(\mathrm{P}>0.05)$ for the urinary excretion of nitrogen (UN) and nitrogen balance $(\mathrm{NB})$, the increase in UAs increased $(\mathrm{P}<0.05)$ urinary urea nitrogen (UUN) and the contribution of nitrogen-urea in $\mathrm{N}$ urinary excretion linearly, and reduced $(\mathrm{P}<0.05)$ the milk nitrogen/milk $\mathrm{N}$ urine ratio (Table 7).

These results demonstrate the even utilizing sugarcane with a high content of sugar, the increase in the level of urea elevates ureagenesis and losses of nitrogen compounds $(\mathrm{N})$ in the urine, reducing the utilization efficiency of the $\mathrm{N}$, increasing the energy expenditure and the environmental liability.

The elevation $(\mathrm{P}<0.05)$ in PUN indicates that at least part of the amount of ammonia in the rumen environment increased by the elevation of the levels of urea in the sugarcane was not assimilated by the rumen microbiota. As a consequence, the blood flow of ammonia absorbed by the rumen epithelium and ureagenesis increased. It must be brought into evidence, however, that the maximum value observed for the PUN is below the threshold value recommended $(200 \mathrm{mg} / \mathrm{dL})$, above which the reproductive functions are compromised by excess of circulating ammonia (NRC, 2001).

The elevation $(\mathrm{P}<0.05)$ in the excretion of UUN demonstrates that the increase in the ureagenesis rate supplanted the ruminal recycling of urea via saliva end epithelium, thereby reducing the utilization efficiency

Table 5 - Digestibility of diets in dairy cows fed different UAs levels in sugarcane

\begin{tabular}{|c|c|c|c|c|c|c|c|}
\hline \multirow{2}{*}{ Item } & \multicolumn{4}{|c|}{ UAs in sugarcane ( $\mathrm{g} / \mathrm{kg}$ as fed) } & \multicolumn{2}{|c|}{ Effect (P-value) } & \multirow{2}{*}{$\mathrm{CV}(\%)$} \\
\hline & 0 & 4 & 8 & 12 & Linear & Quadratic & \\
\hline \multicolumn{8}{|c|}{$\mathrm{g} / \mathrm{g}$} \\
\hline Dry matter digestibility & 0.7256 & 0.7167 & 0.7141 & 0.7266 & 0.9906 & 0.1799 & 3.56 \\
\hline Organic matter digestibility & 0.7331 & 0.7300 & 0.7287 & 0.7392 & 0.6163 & 0.3816 & 3.46 \\
\hline Ether extract digestibility & 0.7641 & 0.7531 & 0.7668 & 0.7874 & 0.4948 & 0.5714 & 11.96 \\
\hline Crude protein digestibility & 0.8114 & 0.8060 & 0.7899 & 0.7944 & 0.1514 & 0.6324 & 4.27 \\
\hline NDFap digestibility & 0.4507 & 0.4384 & 0.4183 & 0.4562 & 0.9676 & 0.2241 & 15.21 \\
\hline NFCap digestibility & 0.9150 & 0.9250 & 0.9241 & 0.9239 & 0.3007 & 0.3627 & 2.02 \\
\hline Total digestible nutrients & 0.6998 & 0.7020 & 0.6993 & 0.7111 & 0.2908 & 0.4722 & 3.14 \\
\hline
\end{tabular}

UAs - mixture consisting of 9 parts of urea: 1 part of ammonium sulphate; CV - coefficient of variation.

NDFap - neutral detergent fiber corrected for residual ash and protein; NFCad - non-fibrous carbohydrates corrected for residual ash and protein. 
Table 6 - Productive performance of dairy cows fed different UAs levels in sugarcane

\begin{tabular}{|c|c|c|c|c|c|c|c|}
\hline \multirow{2}{*}{ Item } & \multicolumn{4}{|c|}{ UAs levels in sugarcane ( $\mathrm{g} / \mathrm{kg}$ as fed) } & \multicolumn{2}{|c|}{ Effect (P-value) } & \multirow{2}{*}{$\mathrm{CV}(\%)$} \\
\hline & 0 & 4 & 8 & 12 & Linear & Quadratic & \\
\hline Milk yield $(\mathrm{kg} / \mathrm{d})$ & 12.86 & 12.50 & 13.00 & 11.97 & 0.1676 & 0.3393 & 9.18 \\
\hline $3.5 \%$-fat corrected milk $(\mathrm{kg} / \mathrm{d})$ & 13.66 & 12.81 & 13.22 & 12.34 & 0.1331 & 0.9063 & 14.46 \\
\hline Milk crude protein $(\mathrm{g} / \mathrm{kg})$ & 34.5 & 34.1 & 34.6 & 34.4 & 0.9819 & 0.9038 & 6.77 \\
\hline Lactose $(\mathrm{g} / \mathrm{kg})$ & 43.8 & 44.0 & 42.2 & 44.2 & 0.7868 & 0.1150 & 4.36 \\
\hline Solids $(\mathrm{g} / \mathrm{kg})$ & 127.8 & 126.5 & 124.9 & 127.5 & 0.7822 & 0.3559 & 5.43 \\
\hline
\end{tabular}

UAs - mixture consisting of 9 parts of urea: 1 part of ammonium sulphate; $\mathrm{CV}$ - coefficient of variation.

${ }^{1}$ Milk yeld/dry matter intake.

Table 7 - Markers of nitrogen compound metabolism of dairy cows fed different UAs levels in sugarcane

\begin{tabular}{|c|c|c|c|c|c|c|c|}
\hline \multirow{2}{*}{ Item } & \multicolumn{4}{|c|}{ UAs levels in sugarcane ( $\mathrm{g} / \mathrm{kg}$ as fed) } & \multicolumn{2}{|c|}{ Effect (P-value) } & \multirow{2}{*}{$\mathrm{CV}(\%)$} \\
\hline & 0 & 4 & 8 & 12 & Linear & Quadratic & \\
\hline Urinary urea nitrogen $(\mathrm{g} / \mathrm{d})$ & 46.74 & 90.34 & 98.42 & 107.5 & $0.0006^{1}$ & 0.0958 & 36.73 \\
\hline Urinary urea nitrogen $(\mathrm{g} / \mathrm{g} \mathrm{UN})$ & 0.47 & 0.66 & 0.74 & 0.72 & $0.0398^{2}$ & 0.3869 & 30.98 \\
\hline Nitrogen intake (g/d) & 261.0 & 263.4 & 262.8 & 263.7 & 0.7242 & 0.9685 & 6.65 \\
\hline Fecal nitrogen $(\mathrm{g} / \mathrm{d})$ & 49.2 & 51.1 & 55.2 & 54.2 & 0.2580 & 0.5815 & 14.43 \\
\hline Fecal nitrogen (g/g UN) & 0.19 & 0.19 & 0.21 & 0.21 & 0.1514 & 0.6324 & 17.44 \\
\hline Milk nitrogen $(\mathrm{g} / \mathrm{d})$ & 71.0 & 68.2 & 71.9 & 65.9 & 0.7985 & 0.5473 & 10.13 \\
\hline Urinary nitrogen $(\mathrm{g} / \mathrm{g} \mathrm{UN})$ & 0.38 & 0.52 & 0.51 & 0.56 & 0.0533 & 0.4389 & 38.14 \\
\hline Nitrogen balance $(\mathrm{g} / \mathrm{d})$ & 41.78 & 7.48 & 2.47 & -5.35 & 0.1129 & 0.6158 & 908.96 \\
\hline Nitrogen balance (g/g UN) & 0.16 & 0.03 & 0.09 & -0.02 & 0.0856 & 0.5222 & 1.236 .1 \\
\hline Milk nitrogen $(\mathrm{kg} / \mathrm{d}) /$ Urinary nitrogen $(\mathrm{g} / \mathrm{d})$ & 0.13 & 0.09 & 0.10 & 0.08 & $0.0187^{3}$ & 0.1216 & 46.71 \\
\hline
\end{tabular}

UAs - mixture consisting of 9 parts of urea: 1 part of ammonium sulphate; CV - coefficient of variation.

UN - urinary nitrogen.

$\hat{\mathrm{Y}}=63.2394+41.7679 . \mathrm{UAs}^{2}=0.3237$

$2 \hat{\mathrm{Y}}=55.9032+19.8252 . \mathrm{UAs} \mathrm{R}^{2}=0.1979$

$3 \hat{\mathrm{Y}}=0.1204-0.02816$. .UAs $\mathrm{R}^{2}=0.1393$.

of the nitrogen compounds (Van Amburgh \& Peterson, 2004). The decrease $(\mathrm{P}<0.05)$ in $\mathrm{N}$ utilization efficiency is possibly related to decrease in the efficiency of capture of the available $\mathrm{N}$ by the rumen microbiota. The drop in the efficiency of capture of available $\mathrm{N}$ with increased urea in the sugarcane, in turn, might have been caused by mechanisms of saturation of the microbial enzymatic systems with increase in the amount of available ammonia, as well as by a change in the available $\mathrm{N}$ composition.

The possibility of utilization of ammonia as a source of nitrogen for the synthesis of amino acids by the rumen microbiota is highly variable and depends on, among other factors, the type of carbohydrate available (Wallace et al., 1997). In fact, rumen bacteria which degrade carbohydrates associated with the cell wall of plants are more adept to utilize ammonia as a source of nitrogen in relation to those which degrade non-structural carbohydrates (Russell et al., 1992). Thus, because in the diets utilized the carbohydrates were mostly non-fibrous ( $75.9 \%$ of the total carbohydrates), the increase in NPN fraction to the detriment of the truly digestible fraction possibly contributed to decrease the conversion of available $\mathrm{N}$ into microbial $\mathrm{N}$ (NRC, 2001).
With this, reductions in the synthesis of rumen microbial protein and consequently in the milk yield with increase in the level of urea were expected. However, as previously stated, there was no effect on the production and composition of the milk, probably because of the increase in available $\mathrm{N}$ in the rumen, which compensated the decrease in its utilization efficiency by the rumen microbiota.

The elevated UUN losses has important energy implications to the animal, since $12 \mathrm{kcal}$ energy $/ \mathrm{N}$ are released, being converted into urea in the process of ureagenesis (Van Soest, 1994). Estimating an increase $(\mathrm{P}<0.05)$ of $41.8 \mathrm{~g} \mathrm{UN}$ for each $10 \mathrm{~g}$ of UAs $/ \mathrm{kg}$ of sugar cane (Table 8), we can estimate increase in energy expenditure of $502 \mathrm{Kcal}$ for each $10 \mathrm{~g}$ of UAs $/ \mathrm{kg}$ of sugarcane. Considering the requirement of net energy of $700 \mathrm{Kcal}$ to produce $1 \mathrm{~kg}$ milk with $3.6 \%$ fat and $3.2 \%$ crude protein (NRC, 2001), this energy expenditure is equivalent to a milk yield of $0.7 \mathrm{~kg} /$ day. However, despite the lack of effect on milk production in this study, it is expected that the increase in energy expenditure will limit the use of higher UAs levels in cows of higher yield, but this still needs to be investigated. 


\section{Conclusions}

The mixture of urea and ammonium sulfate $(9: 1)$ can be used at up to $12 \mathrm{~g} / \mathrm{kg}$ natural matter in sugarcane with a Brix value of $21.9^{\circ}$ in diets for dairy cows producing less than $15 \mathrm{~kg}$ milk/day without affecting performance; however, the utilization efficiency of the nitrogen compounds ingested is reduced.

\section{References}

CASALI, A.O. Procedimentos metodológicos in situ na avaliação do teor de compostos indigestíveis em alimentos e fezes de bovinos. 2006. 47f. Dissertação (Mestrado em Zootecnia) Universidade Federal de Viçosa, Viçosa, MG.

CHALUPA, W.; BAILE, C.A.; McLAUGHLIN, C.L. et al. Effect of introduction of urea on feeding behavior Holstein heifers. Journal of Dairy Science, v.62, p.1278-1284, 1979.

CHIZZOTTI, M.L.;VALADARES FILHO, S.C.; VALADARES, R.F.D. et al. Determination of creatinine excretion and evaluation of spot urine sampling in Holstein cattle. Livestock Science, v.113, p.218-225, 2008.

COSTA, M.G.; CAMPOS, J.M.S.; VALADARES FILHO, S.C. et al. Desempenho produtivo de vacas leiteiras alimentadas com diferentes proporções de cana-de-açúcar e concentrado ou silagem de milho na dieta. Revista Brasileira de Zootecnia, v.34, n.6, p.2437-2445, 2005.

DETMANN, E.; PAULINO, M.F.; VALADARES FILHO, S.C. et al. Fatores controladores de consumo em suplementos múltiplos fornecidos ad libitum para bovinos manejados a pasto. Caderno Técnico de Veterinária e Zootecnia, v.55, p.73-93, 2007.

DETMANN, E.; PAULINO, M.F.; VALADARES FILHO, S.C. et al. Avaliação nutricional de alimentos ou de dietas? Uma abordagem conceitual. In: SIMPÓSIO INTERNACIONAL DE GADO DE CORTE, 6., 2008, Viçosa, MG. Anais... Viçosa, MG: Universidade Federal de Viçosa, Departamento de Zootecnia, 2008. p.21-52.

FERNANDES, A.M. Valor nutritivo da cana-de-açúcar (Saccharum spp.), em função dos ciclos de produção precoce e intermediário e da idade de corte. 2001. Tese (Doutorado em Zootecnia) - Universidade Federal de Viçosa, Viçosa, MG.

HALL, M.B. Calculation of non-structural carbohydrate content of feeds that contain non-protein nitrogen. Gainesville: University of Florida, 2000. P.A-25 (Bulletin 339).

HUBER; J.T.; COOK, R.M. Influence of site of administrations of urea on voluntary intake of concentrate by lactating cows. Journal of Dairy Science, v.55, p.1470-1473, 1972.

INTERNATIONAL DAIRY FEDERATION - IDF. Whole milk. Determination of milkfat, protein and lactose content Guide for the operation of mid-infra-red instuments. Bruxelas, 1996. 12p. (IDF Standard $141 \mathrm{~B}$ ).

LANZAS, C. et al. A revised CNCPS feed carbohydrate fractionation scheme for formulating rations for ruminants. Animal Feed Science and Technology, v.136, n-3-4, p.167-190, 2007.

LICITRA, G.; HERNANDEZ, T.M.; VAN SOEST, P.J. Standardization of procedures for nitrogen fractionation of ruminant feeds. Animal Feed Science and Technology, v.57, n.4, p.347-358, 1996.

MELO, A.A.S.; FERREIRA, M.A.; VÉRAS A.S.C. et al. Substituição parcial do farelo de soja por uréia e palma forrageira (opuntia ficus indica mill) em dietas para vacas em lactação. I. desempenho. Revista Brasileira de Zootecnia, v.32, n.3, p.727-736, 2003.

MERTENS, D.R. Gravimetric determination of amylase-treated neutral detergent fiber in feeds with refluxing in beaker or crucibles: collaborative study. Journal of AOAC International, v.85, p.1217-1240, 2002.

NATIONAL RESEARCH COUNCIL - NRC. Nutrient requirements of dairy cattle. 7.ed. Washington, D.C.: National Academy Press, 2001. 381p.

NOCEK, J.E.; RUSSELL, J.B. Protein and energy as an integrated system. relationship of ruminal protein and carbohydrate availability to microbial synthesis and milk production. Journal of Dairy Science, v.71, p.2070-2107, 1988.

OLIVEIRA, A.S.; VALADARES, R.F.D.; VALADARES FILHO, S.C. et al. Produção de proteína microbiana e estimativas das excreções de derivados de purinas e de uréia em vacas lactantes alimentadas com rações isoprotéicas contendo diferentes níveis de compostos nitrogenados não-protéicos. Revista Brasileira de Zootecnia, v.30, n.5, p.1621-1629, 2001.

OLIVEIRA, M.M.N.F; TORRES, C.A.A.; VALADARES FILHO, S.C. et al. Uréia para vacas leiteiras no pós-parto: desempenhos produtivo e reprodutivo. Revista Brasileira de Zootecnia, v.33, n.6, p.2266-2273, 2004 (supl.3).

RANGEL, A.H.N.; CAMPOS, J.M.S.; VALADARES FILHO, S.C. et al. Produção, composição do leite e concentração de nitrogênio uréico no soro de vacas alimentadas com cana-de-açúcar corrigida. Revista Caatinga, v.21, n.4, p.6-11, 2008.

RUSSELL, J.B.; O'CONNOR, C.D.; FOX, D.G. et al. A net carbohydrate and protein system for evaluating cattle diets. I. Ruminal fermentation. Journal of Animal Science, v.70, n.11, p.3562-3577, 1992.

SKLAN, D.; ASHKENAZI, R.; BRAUN, A. et al. Fatty acids, calcium soaps of fatty acids and cottonseeds fed to high yielding cows. Journal of Dairy Science, v.75, p.2463-2472, 1992.

SILVA, R.M.N.; VALADARES, R.F.D.; VALADARES FILHO, S.C. et al. Uréia para vacas em lactação. 1. consumo, digestibilidade, produção e composição do leite. Revista Brasileira de Zootecnia, v.30, n.5, p.1639-1649, 2001a.

SILVA, R.M.N.; VALADARES, R.F.D.; VALADARES FILHO, S.C. et al. Uréia para vacas em lactação. 2. estimativas do volume urinário, da produção microbiana e da excreção de uréia. Revista Brasileira de Zootecnia, v.30, n.6, p.1948-1957, 2001b.

SILVA, D.J.; QUEIROZ, A.C. Análise de alimentos: métodos químicos e biológicos. 3.ed. Viçosa, MG: UFV, 2002. 235p.

VALADARES FILHO, S.C.; VALADARES, R.D.F. Recentes avanços em proteína na nutrição de vacas leiteiras. In: II SINLEITE - SIMPÓSIO INTERNACIONAL: NOVOS CONCEITOS EM NUTRIÇÃO, 2001, Lavras. Anais... Lavras, 2001. p.229-247.

VAN AMBURGH, M.E.; PETERSON., E.B. How much nitrogen can a cow recycle? In: CORNELL NUTRITION CONFERENCE, 2004, Syracuse. Proceedings... Syracuse, NY, 2004. p.179-188.

VAN SOEST, P.J. Nutritional ecology of the ruminants. 2.ed. Ithaca: Cornell University, 1994. 476p.

WALLACE, R.J.; ONODERA, R.; COTTA, M.A. Metabolism of nitrogen-containing compounds. In: HOBSON, P.N.; STEWART, C.S. (Eds.). The rumen microbial ecosystem. 2.ed. London: Chapmann \& Hall, 1997. p.283-328.

WEISS, W.P. Energy prediction equations for ruminant feeds. In: CORNELL NUTRITION CONFERENCE FOR FEED MANUFACTURERS, 61., 1999, Ithaca. Proceedings... Ithaca: Cornell University, 1999. p.176-185.

WILSON, G.; MARTZ, F.A.; CAMPBELL, J.R. et al. Evaluation of factors responsible for reduced voluntary intake of urea for ruminants. Journal of Animal Science, v.41, p.1431-1437, 1975. 